zeszyt 152, 2018, 119-132

doi: 10.4467/20833113PG.17.034.8257

Instytut Geografii i Gospodarki Przestrzennej UJ

Wydawnictwo Uniwersytetu Jagiellońskiego

\title{
WPEYW ZMIAN POZIOMU MORZA I PROCESÓW FLUWIALNYCH NA POŁOŻENIE UJŚCIOWEGO ODCINKA PIAŚNICY I LITODYNAMIKE, OSADÓW KORYTOWYCH
}

\author{
Ewa Szymczak, Dorota Zabtocka
}

\section{Impact of sea level changes and fluvial processes on the location of the Piaśnica River mouth and the lithodynamic of bed sediments}

Abstract: The aim of the article is to analyse changes in the channel layout of the Piaśnica River estuary and the lithodynamic characteristic of bed deposits as a consequence of sea level changes. The analysis is based on the results of measurements in the river estuary conducted in the years 2014-2015. The data of daily average sea level were obtained from the Institute of Meteorology and Water Management (IMiGW) station in Władyslawowo and Łeba. The research documented distinct changes in the position of the riverbed. Analyses of textual indicators were conducted i.e. mean grain size $\left(M_{Z}\right)$, standard deviation $\left(\sigma_{I}\right)$, skewness $\left(S_{k l}\right)$ and kurtosis $\left(K_{G}\right)$ were calculated according to Folk and Ward formulas (1957) using the Gradistat software. Based on the abovementioned data conclusions were made about the changing conditions of the river sediment transport.

Keywords: Piaśnica River, channel-bed sediments, grain size parameters

Zarys treści: Celem artykułu jest przedstawienie zmian położenia koryta rzeki Piaśnicy w jej ujściowym odcinku oraz charakterystyka litodynamiki osadów korytowych, jako konsekwencji zmian poziomu morza. Analizę oparto na wynikach pomiarów prowadzonych w ujściowym odcinku rzeki w latach 2014-2015. Wykorzystano dane dotyczące dobowych stanów morza, 
pochodzące ze stacji Instytutu Meteorologii i Gospodarki Wodnej (IMGW-PIB) we Władysławowie i Łebie. W czasie prowadzonych badań udokumentowano wyraźne zmiany położenia koryta rzeki. Przeprowadzono analizy uziarnienia osadów korytowych, zinterpretowano wartości wskaźników teksturalnych, tj. średnią średnicę ziarn $\left(\mathrm{M}_{\mathrm{Z}}\right)$, wysortowanie $\left(\sigma_{\mathrm{I}}\right)$, skośność $\left(\mathrm{S}_{\mathrm{kI}}\right)$ oraz spłaszczenie $\left(\mathrm{K}_{\mathrm{G}}\right)$, obliczone metodą Folka i Warda (1957) z wykorzystaniem programu Gradistat. Na ich podstawie wnioskowano o warunkach transportu rumowiska rzecznego na tle zmieniającego się położenia koryta rzeki.

Stowa kluczowe: rzeka Piaśnica, osady korytowe, parametry uziarnienia

\section{Wprowadzenie}

Rzeki Przymorza, choć w całokształcie swej działalności transportowej wnoszą do strefy brzegowej znaczne ilości aluwiów (Cyberski 1980; Szymczak 2002; Szymczak, Piekarek-Jankowska 2007; Szymczak, Szmytkiewicz 2014), często nie mają wystarczającej ilości osadów ani odpowiednio dużej energii do utworzenia charakterystycznych przyujściowych form morfologicznych. Na działalność tych rzek w odcinku ujściowym nakładają się ponadto wahania poziomu morza oraz transportująca i akumulacyjna działalność fal i prądów generujących potoki rumowiska. Czynniki te mają wpływ na kierunek rozwoju ujść rzecznych (Leontjew i in. 1982), ponieważ wpływają na utrzymanie równowagi hydrodynamicznej w ujściowym odcinku cieku. W zależności od szybkości i wielkości zmian poziomu morza mamy do czynienia z ciągłym dostosowywaniem morfologii cieku za pośrednictwem procesów erozji koryta i akumulacji rumowiska (Chow 959; Walling, Fang 2003).

Nakładanie się procesów rzecznych i morskich można wyraźnie obserwować w ujściu Piaśnicy. Dolny odcinek biegu rzeki wraz z ujściem, mimo przeprowadzenia prac w ramach „Programu zabezpieczenia ujściowych odcinków rzek uchodzących do otwartego morza, Zatoki lub Zalewu” wdrożonego na mocy działania wieloletniego „Programu ochrony brzegów morskich” (Instytut Morski w Gdańsku 2012), można w dalszym ciągu uznać za naturalny, co w skali polskiego wybrzeża stanowi wyjątek.

Prace związane z regulacją dolnego odcinka wdrożono po ocenie ryzyka powodziowego w ujściu Piaśnicy, które jest kształtowane przez zespół czynników morskich i lądowych, a ich skutkiem są przekształcenia erozyjno-abrazyjno-akumulacyjne linii brzegowej. W ciągu lat spiętrzenia sztormowe powodowały przede wszystkim zmianę biegu Piaśnicy, przesuwając koryto rzeki pod wydmę, co prowadziło do jej podcinania, zagrażając stabilności wału wydmowego. W 2010 r. dokonano regulacji koryta i przemodelowano bieg rzeki, kierując jej wody nieomal prostopadle do linii brzegowej (Bodziony 2011). Zostało to osiągnięte przez zamocowanie w miejscach preferowanego przebiegu prawego brzegu rzeki drewnianej palisady. 


\section{Położenie obszaru badań}

Piaśnica jest niewielką rzeką, długą zaledwie na 28,6 km (Myśliwy 2010), uchodzącą bezpośrednio do Morza Bałtyckiego (ryc. 1). Uwzględniając przynależność fizycznogeograficzną obszaru badań, rzeka wraz z dorzeczem w większej swej części położona jest na obszarze mezoregionu Wysoczyzny Żarnowieckiej. Odcinek ujściowy znajduje się już w obrębie mierzejowego, akumulacyjnego fragmentu Wybrzeża Słowińskiego (Kondracki 2002). Linia brzegowa w odcinku ujściowym rzeki jest wyrównana, co jest spowodowane intensywnym falowaniem w tym rejonie (Kondracki 2002). Jest to obszar odsłonięty, zatem całkowicie wystawiony na silną działalność wiatru, fal oraz prądów morskich, które decydują o zmianach rzeźby brzegu i przybrzeża.

Piaśnica wypływa z niewielkiego jeziora na wysokości 87 m n.p.m. (Bodziony 2011), przepływa przez Jezioro Żarnowieckie. Przy wypływie, w północnej części jeziora, na krótkim odcinku jest uregulowana i obwałowana, dalej pozbawiona wszelkich umocnień, w dolnym odcinku swojego biegu silnie meandruje, tworząc ok. 40 zakoli i przyjmując charakter rzeki nizinnej (Radtke i in. 2010). Po wypłynięciu z jeziora Piaśnica płynie rozległą, zmeliorowaną równiną akumulacyjną (ryc. 1), Równiną Błot Przymorskich. Kolejno występują tutaj równiny lagunowe i jeziorne, mierzeje i morskie terasy litorynowe, mierzeje postlitorynowe, wąski pas wydm oraz plaża. Pochodzenie tych form związane jest z postglacjalną ewolucją Morza Bałtyckiego, w wyniku której następowały zmiany położenia linii brzegowej. Budowa geologiczna podłoża, obok zmiennych w czasie warunków hydraulicznych przepływu wody oraz transportu rumowiska, warunkuje zróżnicowanie uziarnienia osadów korytowych. Osady powierzchniowe zlewni Piaśnicy, podlegające denudacji, reprezentowane są przez utwory holoceńskie i plejstoceńskie (Ostaficzuk i in. 1976; Ostaficzuk 1978). Są to przede wszystkim morskie piaski plażowe, piaski eoliczne, a dalej piaski i żwiry mierzei i wałów brzegowych. Wzdłuż koryta rzeki występują torfiaste piaski rzeczne i drobnoziarniste piaski rzeczne, a także torfy (Przasnyska 2009).

Piaśnica zasilana jest głównie przez wody podziemne (Bodziony 2011; Komunalny Związek Gmin Dolina Redy i Chylonki, http://kzg.pl/, 12.04.2016). System krążenia wód podziemnych w granicach całego obszaru charakteryzuje się dominacją infiltracyjnego zasilania wodami, które dostarczane są wraz z opadem atmosferycznym, następnie spływają z wysoczyzn morenowych ku równinom nadmorskim i dalej do morza. Zlewnia Piaśnicy zajmuje powierzchnię 310,4 km² (Podziathydrograficzny Polski 1983), w wartości tej zawiera się hydrograficznie przynależąca do zlewni Piaśnicy zlewnia Jeziora Żarnowieckiego, o łącznej powierzchni 249,7 km² (Podziat hydrograficæny Polski 1983). Piaśnica - gdy wypływa z jeziora przez jaz, nazywana jest już Dolną Piaśnicą - ma długość $5 \mathrm{~km}$ (Podziat hydrograficsny Polski 1983) i odprowadza wody z pozostałych 60,7 $\mathrm{km}^{2}$ zlewni. Odcinek ten 
charakteryzuje się bardzo małym spadkiem wynoszącym 0,23\%o. Średni napływ wód przez jaz z jeziora do Piaśnicy wynosi $1,7 \mathrm{~m}^{3} \cdot \mathrm{s}^{-1}$, zasilanie wodami gruntowymi ocenia się na $0,6 \mathrm{~m}^{3} \cdot \mathrm{s}^{-1}$. W ciągu roku zmiany wielkości zasilania nie są duże z powodu istnienia wokół tego obszaru kilku małych jezior (Jarzębińska, Majewski 2009) oraz systemu rowów melioracyjnych.

Pionowe wahania zwierciadła wody w rzece w dolnym biegu zależą nie tylko od zasilania, ale też w dużej części od stanów morza. Sztormowy wiatr dolądowy powoduje wezbrania sztormowe, które są przyczyną powstawania zjawiska cofki w ujściowych odcinkach rzek (Sztobryn i in. 2010), zjawisko to występuje także w dolnym biegu Piaśnicy. Cofka przenosi się wodami rzecznymi i dochodzi do Jeziora Żarnowieckiego, ale nie przenosi się na nie dzięki wspomnianemu jazowi regulacyjnemu (Majewski 1996).

Zmiany poziomu morza odgrywają niebagatelną rolę w kształtowaniu warunków odpływu z lądu. Z wieloletnich badań (1951-2010) wynika, że średni roczny poziom morza na polskim wybrzeżu wzrastał w tempie ok. $2 \mathrm{~cm}$ na dekadę. Dane, z ponadstuletnich obserwacji (1872-2010), pozwalają określić różnicę między maksymalnym a minimalnym poziomem morza, która osiągnęła na posterunkach w Łebie i we Władysławowie odpowiednio $265 \mathrm{~cm}$ i $232 \mathrm{~cm}$ (Wolski, Wiśniewski 2014). Na odcinku wybrzeża Lubiatowo-Karwia w latach 1985-1995 spiętrzenia sztormowe występowały 43 razy, a w latach 1951-1995 aż 103 razy (Dubrawski, Zawadzka 2006). Zauważalny w ostatnich latach wzrost wezbrań sztormowych i średniego poziomu morza na południowym Bałtyku oraz przewidywane zmiany świadczą o zwiększającym się zagrożeniu tymi zjawiskami (IMGW-PIB 2014). W sezonach sztormowych (jesień-zima), gdy poziom wód jest wysoki, zachodzi intensywne rozmywanie wzdłuż całego profilu poprzecznego brzegu. W czasie wiosenno-letnim, przy braku silniejszego falowania i niskim stanie wody, materiał osadowy jest akumulowany (Musielak 2015). Według Zawadzkiej-Kahlau (2008) na odcinku Stilo-Karwia, obejmującym obszar badań, w latach 1988-1997 występowały procesy abrazyjne o różnym natężeniu. Lokalnie obserwowano także procesy akumulacyjne, związane z odbudową plaży i wydm, czas relaksacji brzegu pomiędzy kolejnymi sztormami był jednak zbyt krótki, aby mogły się rozwinąć znaczące procesy wydmotwórcze. Bilans osadów wskazuje na erozję wybrzeża tego rejonu, mimo iż genetycznie jest to obszar typu mierzejowego o charakterze równiny akumulacyjnej (Zawadzka-Kahlau 2008). Zmiany widoczne są również na dostępnych fotografiach z ostatniego dziesięciolecia, kiedy to plaża w Dębkach była szeroka na prawie 100 m, obecnie wartość tego parametru osiąga maksymalnie 20-30 m. 


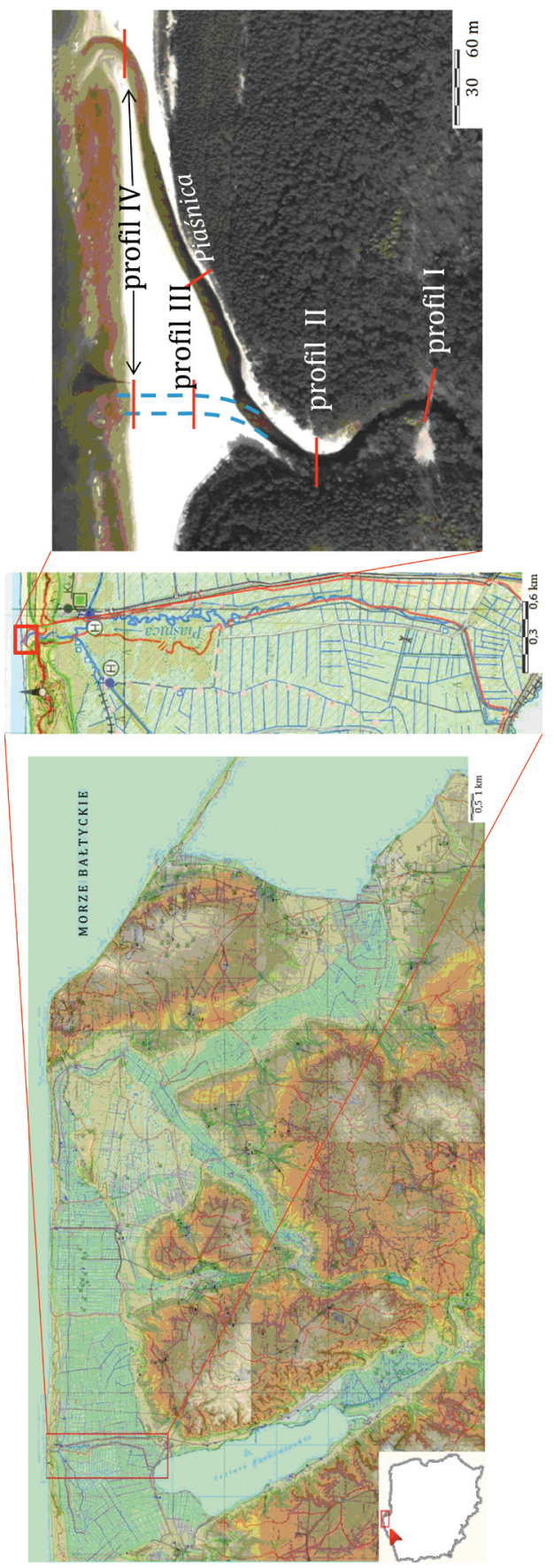

Ryc. 1. Lokalizacja obszaru badań Fig. 1. Location of the study area Źródto: Geoportal 2, http://mapy.geoportal.gov. pl/imap/ (16.07.2017).

Source: Geoportal 2, http://mapy.geoportal.gov. pl/imap/ (16.07.2017). 

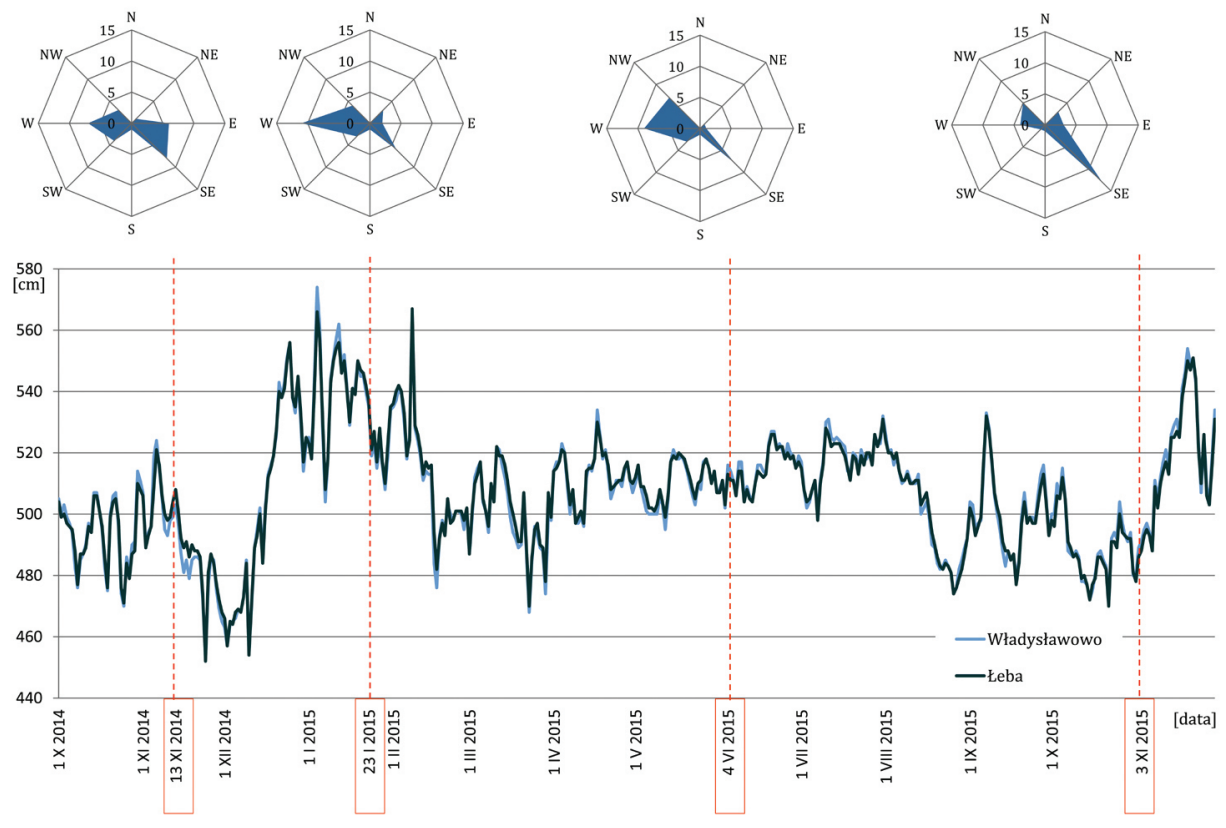

Ryc. 2. Przebieg średnich dobowych poziomów morza na stacji Władysławowo i Łeba (1.10.2014-30.11.2015) oraz kierunki i prędkości prądów powierzchniowych w okresie 30 dni przed pomiarami terenowymi

Fig. 2. Course of daily average sea level in Władysławowo and Łeba stations (1.10.201430.11.2015) and the surface currents direction and speed within 30 days prior to the field measurements

Źródto: IMGW-PIB, http://model.ocean.univ.gda.pl (10.12.2016).

Source: IMGW-PIB, http://model.ocean.univ.gda.pl (10.12.2016). 


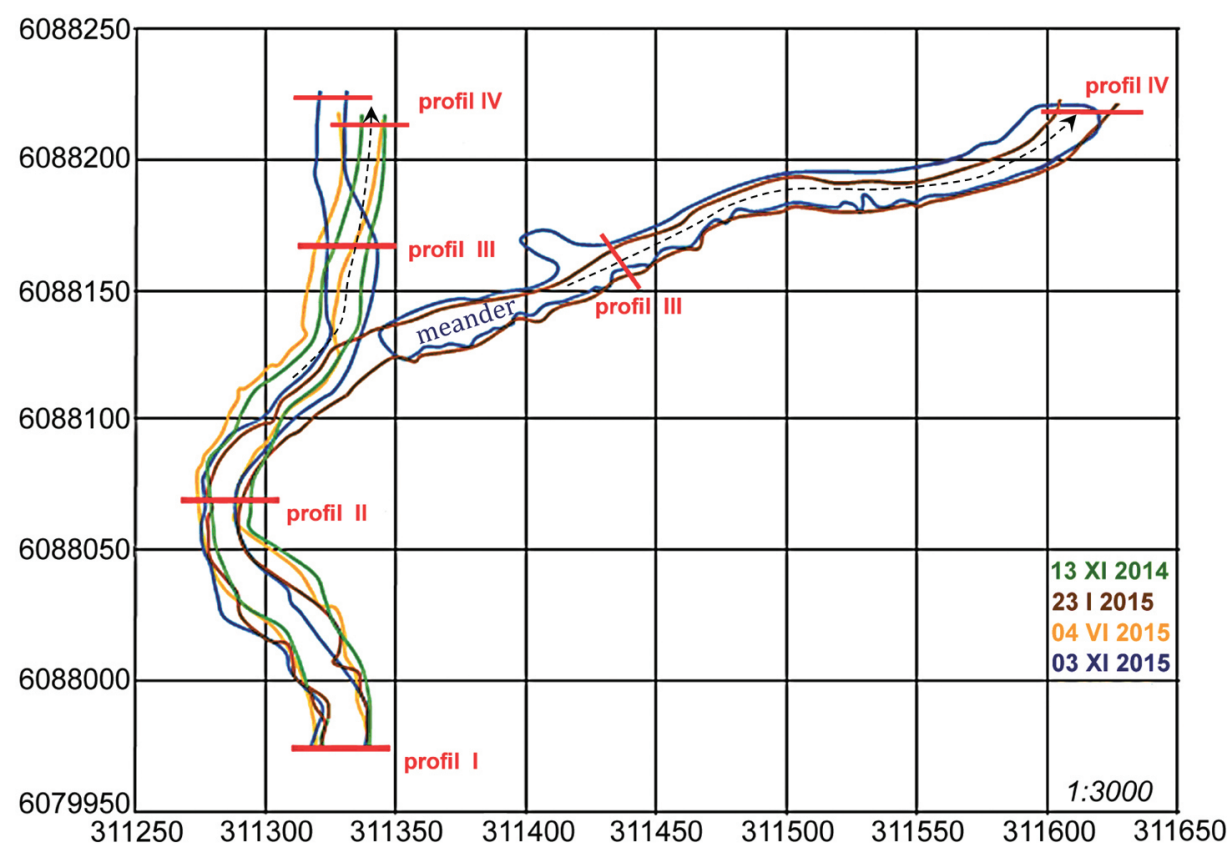

Ryc. 3. Zmiany położenia koryta Piaśnicy w ujściowym odcinku, lokalizacja profili pomiarowych (I-IV), (strzałką zaznaczono odcinki przedstawione na ryc. 4a i b)

Fig. 3. Changes in the channel layout of the Piaśnica River mouth, location of the profile sections (I-IV), (arrows indicate the sections shown in Fig. 4a and b) 


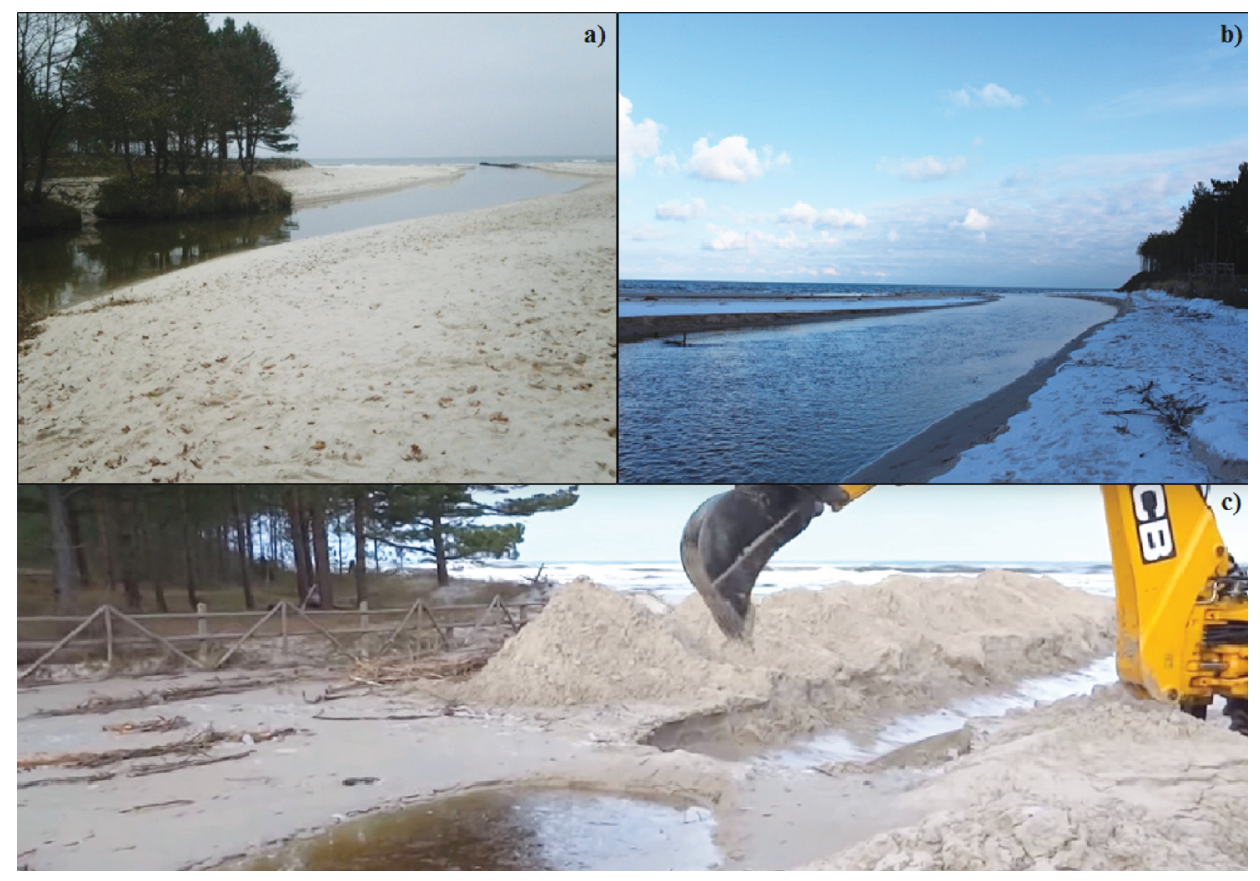

Ryc. 4. Zmiany położenia ujścia Piaśnicy: a) 13 XI 2014; b) 23 I 2015; c) 8 XII 2013

Fig. 4. Changes in the location of the Piaśnica River mouth: a) 13 XI 2014; b) 23 I 2015; c) 8 XII 2013

Fot. / Photo by: a) M. Witak; b) E. Szymczak; c) https://www.youtube.com/watch?v=rUY51NRaiQU (8.02.2017).
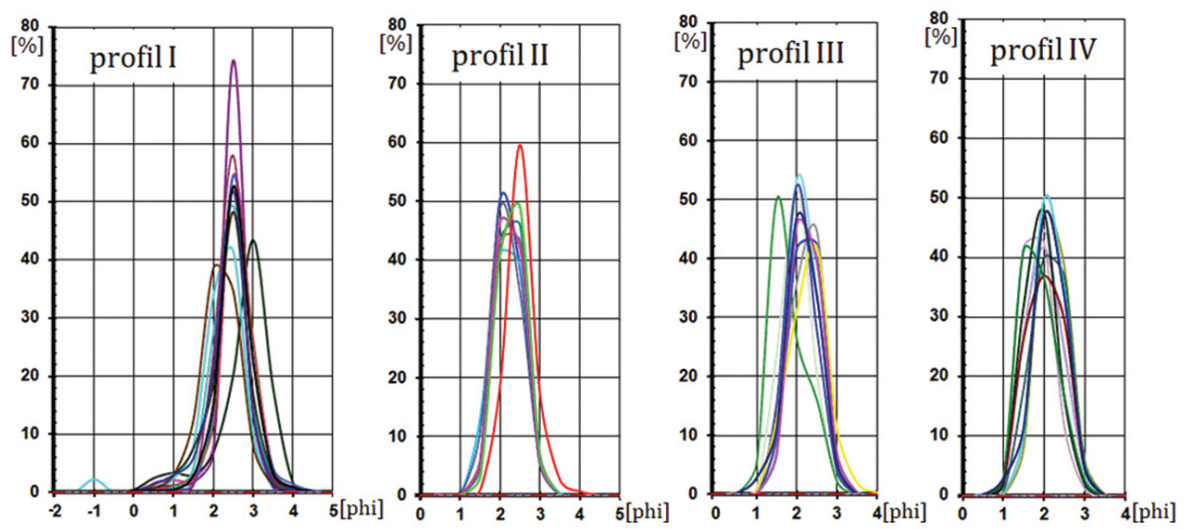

Ryc. 5. Krzywe częstości osadów korytowych w profilach

Fig. 5. Frequency curves of river bed sediments in profiles 

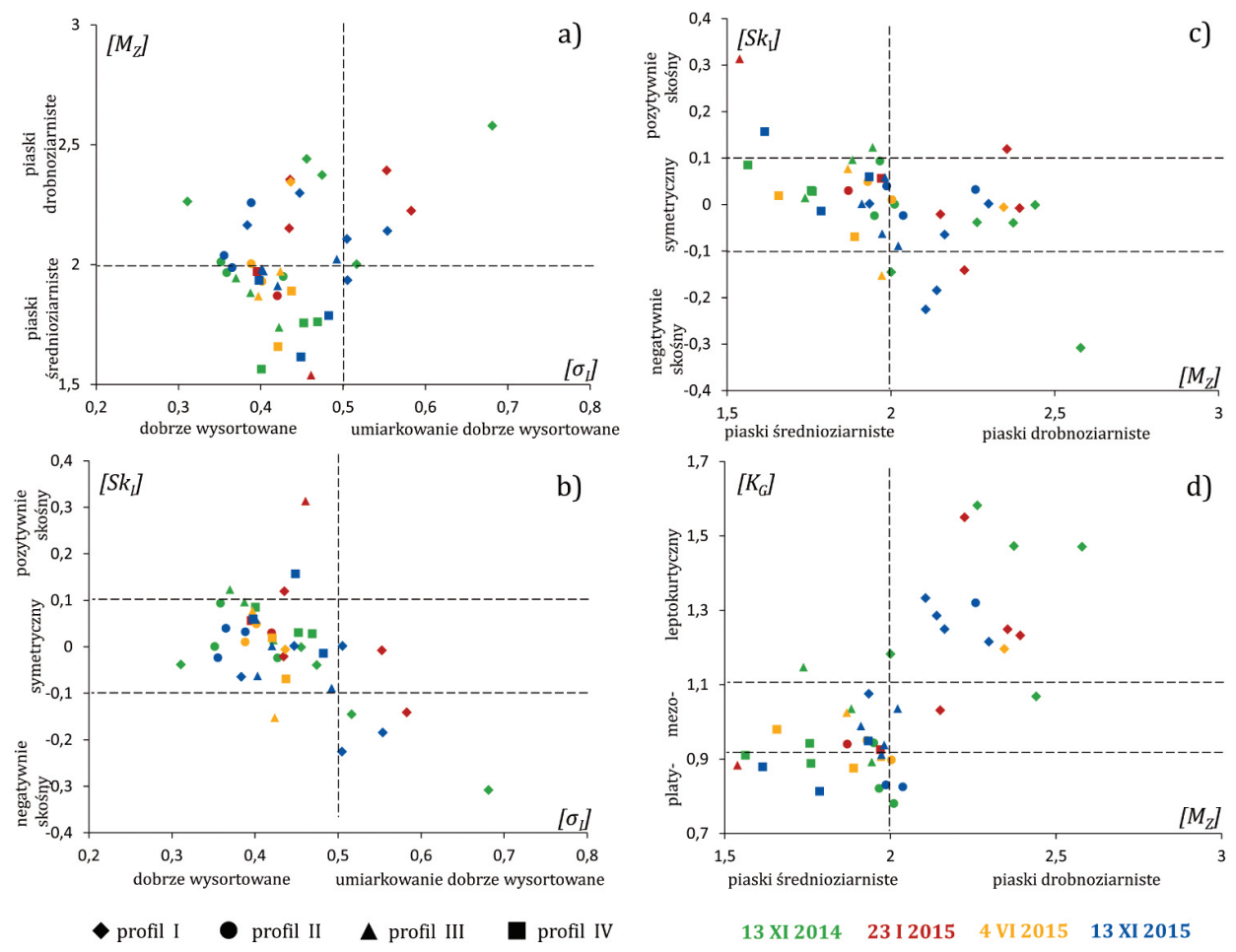

Ryc. 6. Zależność między wartościami wskaźników uziarnienia wg Folka i Warda (1957): a) średnią średnicą i odchyleniem standardowym; b) skośnością i odchyleniem standardowym; c) skośnością i średnią średnicą; d) kurtozą i średnią średnicą

Fig. 6. Relation between textural parameters according to Folk and Word (1957): a) mean grain diameter and standard deviation; b) skewness and standard deviation; c) skewness and mean grain diameter; d) kurtosis and mean grain diameter 


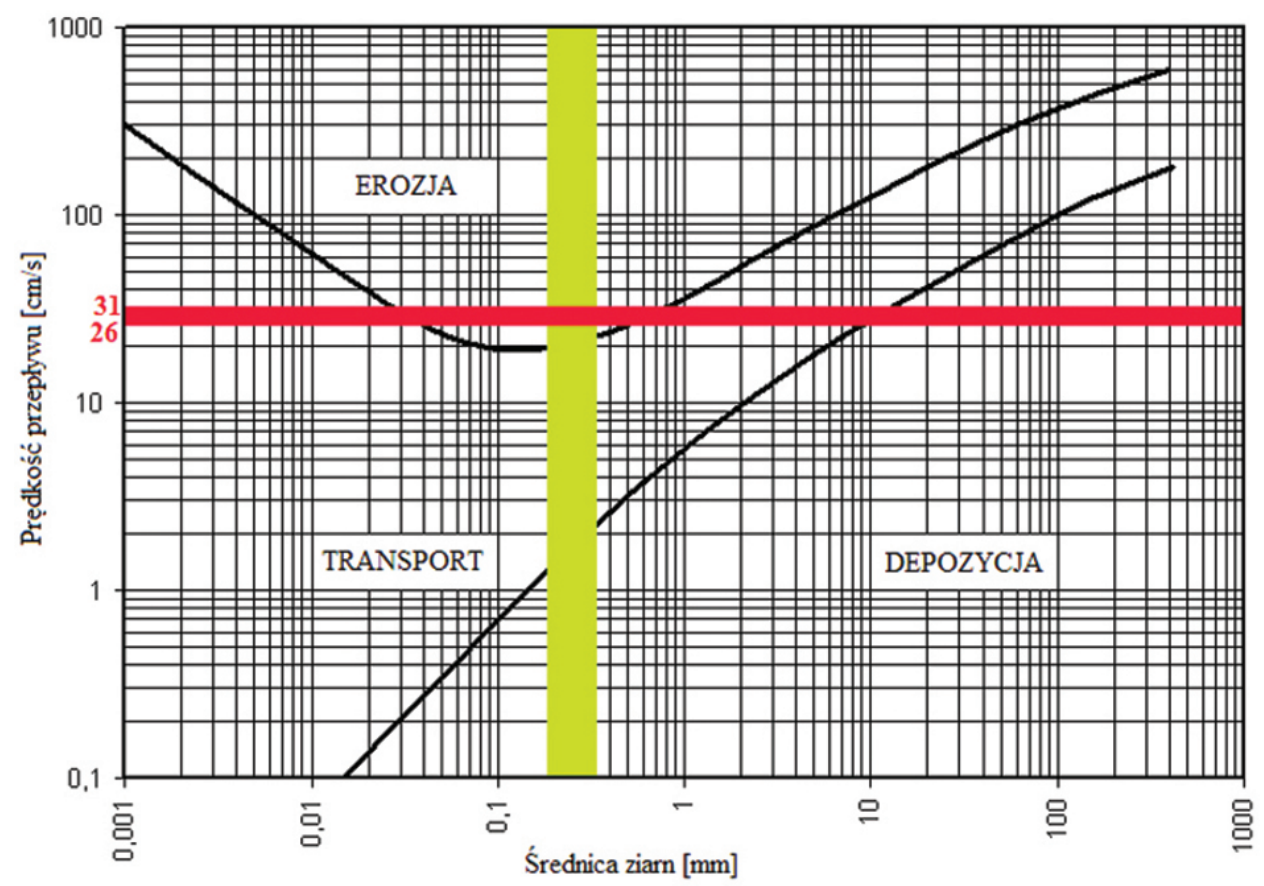

Ryc. 7. Diagram Hjulströma ukazujący średnie prędkości przepływu Piaśnicy w profilu (I) oraz średnią średnicę osadów korytowych (wg Hjulström 1935)

Fig. 7. Hjulström diagram showing an average flow velocity of the Piaśnica River in a profile (I) and an mean grain diameter of bed sediments (after Hjulström 1935) 


\section{Badania terenowe i laboratoryjne}

Badania terenowe rozpoczęto 13 listopada 2014 r., kolejne przeprowadzono 23 stycznia 2015 r., 4 czerwca 2015 r., ostatnią zaś serię pomiarów wykonano 3 listopada 2015 r. Zmiany położenia koryta na odcinku od drewnianego mostu w Dębkach (profil I), do ujścia Piaśnicy do morza (ryc. 1) rejestrowano, prowadząc pomiar odbiornikiem DGPS. Materiał do analiz litologicznych stanowiły próbki osadów korytowych pobrane w czterech profilach (ryc. 1), w strefie nurtu i w odległości 1/6 szerokości koryta od prawego i lewego brzegu (Bajkiewicz-Grabowska i in. 1993). W wyznaczonych profilach przeprowadzono także pomiary głębokości oraz prędkości przepływu celem określenia warunków transportu rumowiska rzecznego. Lokalizacja profili pomiarowych zmieniała się w zależności od położenia koryta rzeki i jego parametrów. W pełni stałym profilem był profil I (ryc. 1) zlokalizowany przy moście w Dębkach (5449'52.7”N 1803'45.2”E) w odległości ok. $300 \mathrm{~m}$ od właściwego ujścia Piaśnicy do morza.

Analizy uziarnienia próbek osadów korytowych wykonano metodą sitową, wykorzystując zestaw sit o średnicach oczek co 0,5 phi (Myślińska 2010). Parametry uziarnienia: średnią średnicę ziarn $\left(M_{Z}\right)$, wysortowanie $\left(\sigma_{I}\right)$, skośność $\left(S_{k I}\right)$ oraz spłaszczenie $\left(K_{G}\right)$ obliczono metodą Folka i Warda $(1957)$ z wykorzystaniem programu Gradistat (Blott, Pye 2001). Wykonano także przegląd dostępnej dokumentacji fotograficznej ukazującej zmiany położenia ujścia rzeki.

Analizę wahań poziomu morza w okresie od 1 października 2014 do 30 listopada 2015 oparto na wynikach obserwacji mareograficznych ze stacji Władysławowo i Łeba uzyskanych z IMGW-PIB, z kolei kierunki prądów powierzchniowych wyznaczono, wykorzystując model ekohydrodynamiczny dla obszaru południowego Bałtyku (http://model.ocean.univ.gda.pl/, 10.12.2016).

\section{Wyniki i dyskusja}

\section{Zmiany położenia ujścia rzeki Piaśnicy}

Celem wyjaśnienia przyczyn zmian położenia ujściowego odcinka Piaśnicy przeanalizowano zmiany poziomu morza oraz kierunki prądów powierzchniowych w okresach bezpośrednio poprzedzających terminy pomiarów. W analizowanym okresie średni poziom wód na badanym odcinku wybrzeża wynosił 506,8 $\pm 0,09 \mathrm{~cm}$, amplituda wahań poziomu morza osiągnęła $121 \mathrm{~cm}$. Najniższe i najwyższe stany wód zaobserwowano na przełomie grudnia 2014 r. i stycznia 2015 r. (ryc. 2).

Pierwszą serię pomiarów (13 XI 2014) poprzedzał okres, w którym zmiany poziomu morza zachodziły przede wszystkim w przedziale stanów średnich między 
480 a $520 \mathrm{~cm}$. Skrajne wartości przekraczały wspomniane granice w konsekwencji czego różnice poziomu morza wyniosły maksymalnie $54 \mathrm{~cm}$ (ryc. 2). W dniu pomiaru poziom morza oscylował między $503 \mathrm{~cm}$ (Władysławowo) i $508 \mathrm{~cm}$ (Łeba). Dominowały prądy powierzchniowe z kierunku SE, E i W (ryc. 2). Piaśnica w takich warunkach prowadziła swoje wody najkrótszą drogą do morza, zwężając wyraźnie koryto w ujściu $(9,2 \mathrm{~m})$ (ryc. 3).

Wyraźny wzrost poziomu morza, z maksymalną wartością $574 \mathrm{~cm}$, nastąpił w styczniu 2015 r. - w okresie poprzedzającym bezpośrednio drugi cykl badań terenowych. Utrzymujący się przez dłuższy czas wysoki poziom morza (średnio ok. $540 \mathrm{~cm}$ ) (ryc. 2) spowodował podniesienie poziomu bazy erozyjnej i zmniejszenia spadku podłużnego rzeki. W takich warunkach doszło do zmiany położenia koryta rzeki, która rozmywała i redeponowała osady plażowe (materiał łatwo podlegający erozji). Skutkiem tych procesów było „przerzucenie” koryta w kierunku wschodnim o ok. 300 m od pierwotnej lokalizacji (ryc. 3). Zaznaczyć należy, że w okresie poprzedzającym pomiary dominowały prądy powierzchniowe z kierunku W, NW i SE (ryc. 2). Samo ujście rzeki pozostawało wyraźnie płytsze i szersze (21,7 m).

Najmniejszą dynamiką zmian poziomu morza w zakresie stanów średnich (500-510 cm) charakteryzował się okres poprzedzający trzeci, czerwcowy, cyk1 pomiarów (ryc. 2). Piaśnica prowadziła wody najkrótszą drogą do morza. Położenie koryta w obrębie plaży było bardzo zbliżone do lokalizacji uzyskanej w pierwszym sezonie, choć samo ujście pozostawało nieco szersze (17 m) (ryc. 3). W okresie bezpośrednio poprzedzającym pomiary prądy powierzchniowe przyjmowały kierunki W, NW i SE (ryc. 2).

Ostatni sezon pomiarowy (XI 2015) poprzedzony był obniżonym, w stosunku do normalnego poziomem morza (o $29 \mathrm{~cm}$ ), stan ten utrzymywał się także w dniu wykonywania pomiarów (ryc. 2). Zmiana położenia bazy erozyjnej warunkowała prostopadły do linii brzegowej przebieg koryta i spowodowała jego pogłębienie. Porównując układ koryta do wcześniejszych obserwacji, można zauważyć, że samo ujście przesunięte jest najbardziej na zachód, co może być spowodowane dominacją prądów powierzchniowych z sektora wschodniego (63\%) (ryc. 2). Szerokość koryta w profilu IV wynosiła ok. 10 m (ryc. 4). Między czerwcem a listopadem, w czasie kiedy nie prowadzono badań terenowych, koryto zmieniło swoje położenie, na co wskazuje obecność odciętego meandru (ryc. 3).

W okresie kilkunastu miesięcy zaobserwować można, że rzeka dostosowuje położenie koryta do aktualnego poziomu morza. Prowadzi swoje wody najkrótszą drogą prosto do morza (ryc. 4a) lub meandruje, układając swoje koryto wzdłuż wydmy i przenosząc ujście w kierunku wschodnim. Długość rzeki na badanym odcinku zmienia się od ok. 260 do ponad 470 m (ryc. 4b). Różnice w położeniu ujścia wzdłuż linii brzegowej wynoszą od 8 do ponad $300 \mathrm{~m}$. Tym samym, na analizowanym odcinku, zmienia się współczynnik rozwinięcia rzeki od 1,15 do 1,36. 
Podczas spiętrzeń sztormowych, w czasie których pojawiają się także prądy skierowane prostopadle do brzegu, w koryto wkracza cofka. W skrajnych sytuacjach dochodzi do zasypania ujścia osadami morskimi. Tak stało się podczas przejścia huraganu, zwanego orkanem Ksawery, między 4 a 10 grudnia 2013 r. Koryto Piaśnicy zostało wówczas wypełnione osadami sztormowymi, w rezultacie czego doszło do zatrzymania odpływu, spiętrzenia i wezbrania wody w korycie rzeki (ryc. 4c).

Poza zmianą położenia zauważalne są także przeobrażenia profilu podłużnego i przekroju poprzecznego podwodnej części koryta, które są wypadkową oddziaływań zmian poziomu morza oraz naturalnych procesów korytotwórczych, tj. zmian przepływu wody i ilości transportowanego rumowiska. Pojawiają się przewężenia czy też niewielkie rozszerzenia koryta związane z procesami erozji bocznej, typowej dla rzek typu krętego czy meandrującego. Po nałożeniu poszczególnych profili podłużnych (ryc. 3) zauważyć można, w których odcinkach zaszły wspomniane zmiany.

Szerokość koryta rzeki w profilu I zmieniała się w zakresie 18,7-20 m, a głębokość maksymalna od 1,35 do 1,58 m. Za równie stabilny fragment koryta można uznać odcinek, w którym zlokalizowano profil II. Szerokość zmieniała się od 12,2 do $13,5 \mathrm{~m}$, a w przekroju poprzecznym największe głębokości występowały przy podlegającym erozji, lewym brzegu. Największe zmiany zachodziły na odcinku, w którym wyznaczono profil III, gdzie następowało przerzucanie koryta, oraz w samym ujściu (profil IV). Szerokość zmieniała się odpowiednio od 15,1 do 19,7 m oraz od 9,2 do $23,7 \mathrm{~m}$.

\section{Charakterystyka osadów korytowych}

Osady korytowe składają się z frakcji piaszczystej, której udział wynosi 97,7-100\%. Udział pozostałych frakcji żwirowej i mułkowej wynosi maksymalnie 2,3\% i 0,5\%. Analiza krzywych uziarnienia (ryc. 5) wykazała, że w badanych osadach występują wyłącznie krzywe jednomodalne. Mody skupiają się w wartościach 2-3 phi w profilu I, 2-2,5 phi w profilu II, 1,5-2,5 phi w profilu III, i 1,5-2 phi w profilu IV.

Obraz rozmieszczenia typów litologicznych osadów w ujściowym odcinku Piaśnicy został sporządzony z wykorzystaniem wskaźnika charakteryzującego przeciętną wielkość ziarn $\left(M_{Z}\right)$. Osady korytowe reprezentowane są przez dwa typy litologiczne: piaski drobnoziarniste i średnioziarniste (ryc. 6a). Wartości parametru wskazują, że w profilu I, niezależnie od okresu poboru próbek, dominują piaski drobnoziarniste (2,02-2,58 phi), jednorazowo stwierdzono występowanie w centralnej części koryta piasków średnioziarnistych (1,94 phi). W profilu II piaski drobnoziarniste występują obok średnioziarnistych (1,87-2,25 phi), w każdym z kolejnych profili średnica ziarn maleje, co pozwala sklasyfikować osady korytowe jako piaski średnioziarniste (1,54-2,0 phi). Zmieniająca się wraz z biegiem rzeki w ujściowym odcinku średnia średnica ziarn powiązana jest ze spadkiem prędkości płynięcia, a co za tym idzie, 
ze zmniejszającą się siłą transportową rzeki, w wyniku czego następuje depozycja rumowiska transportowanego w zawiesinie gradacyjnej (2-4,5 phi) oraz saltacji (0,5-2 phi) (Allen i in. 1972). Ponadto osady korytowe na odcinkach profilu II, III i IV mogą być zasilane frakcjami piasków transportowanych eolicznie. Osady pochodzące z wałów wydm przednich oraz osady plażowe w obszarze Mierzei Karwieńskiej należą do piasków średnio- i drobnoziarnistych, których przeciętna średnica ziarn mieści się w przedziale 1,7-2,3 phi (Łabuz, Sydor 2016).

Wartość odchylenia standardowego $\left(\sigma_{I}\right)$ charakteryzuje się mniejszym zróżnicowaniem przestrzennym i czasowym. Osady korytowe reprezentują dwa stopnie wysortowania: dobry oraz umiarkowanie dobry (ryc. 6a). Największe zróżnicowanie wysortowania wykazują osady w profilu I - od umiarkowanie do dobrze wysortowanych $(0,31-0,68)$. W pozostałych odcinkach osady korytowe są dobrze wysortowane (0,35-0,49). Zbliżone wartości parametru $(0,21-0,41)$ występują w przenoszonych przez wiatr osadach wydmowych i plażowych Mierzei Karwieńskiej (Łabuz, Sydor 2016).

Diagramy zależności wskaźników uziarnienia wg Folka i Warda (1957) w przypadku zestawienia $M_{Z}$ i $\sigma_{I}$ obrazują wzrost stopnia wysortowania osadów wraz ze spadkiem średniej średnicy (ryc. 6a), co jest charakterystyczne dla osadów fluwialnych facji korytowej. Zgodnie z interpretacją przedstawioną przez Mycielską-Dowgiałło (2007) układ taki charakterystyczny jest dla środowisk o przewadze procesów sortowania w obrębie grubszej frakcji i okresowej dostawie słabiej wysortowanego materiału transportowanego w zawieszeniu.

Zaobserwowaną cechą wspólną w każdym z terminów przeprowadzonych badań jest pokrycie większej części koryta rzecznego przez osady o rozkładach uziarnienia symetrycznych względem wartości modalnej $\left(S_{k I}\right)$. Największe zmiany parametru występują w profilu I oraz III. W profilu I pobrano próbki charakteryzujące się ujemną skośnością typową dla osadów korytowych (Mycielska-Dowgiałło, Ludwikowska-Kędzia 2011). Wskazuje to na przewagę prędkości większych od przeciętnych, skutkiem czego jest uruchamianie drobniejszych frakcji osadów korytowych, ich transport i redepozycja. Tym samym w tym profilu występują frakcje piasków gruboziarnistych i żwirów, których łączny udział wynosi przeciętnie 3,1\%, podczas gdy w pozostałych profilach nie przekracza 1,6\%. Dodatnie wartości skośności w profilu III, w którym następuje ,przerzucanie” koryta wynikające ze zmiany biegu rzeki, pozwalają wnioskować o formowaniu się osadów w warunkach prędkości przepływu mniejszych od przeciętnej, co skutkuje unieruchamianiem ziarn frakcji 0,5-2 phi, transportowanych w saltacji (Visher 1969). Sytuacja ta wystąpiła w drugim sezonie pomiarowym, gdy wyższy poziom morza spowodował spadek prędkości przepływu.

Zestawienie wskaźników $S_{k I}$ i $M_{Z}$ (ryc. 6c) pozwala zaobserwować, że początkowo wraz z drobnieniem frakcji (1,4-2 phi) następuje spadek wskaźnika skośności, a następnie (>2 phi) - jego wzrost. Na diagramie zależności skośności i wysortowania (ryc. 6b) zauważalny jest wzrost wysortowania osadów wraz ze wzbogacaniem ich 
we frakcje transportowane w saltacji (Racinowski i in. 2001). Świadczy to o spadku zdolności transportowej rzeki (szczególnie w profilach II-IV), w konsekwencji następuje sedymentacja niesionego materiału. Za wzrost udziału w osadach korytowych bardzo dobrze i dobrze wysortowanych piasków średnioziarnistych (Łabuz, Sydor 2016) odpowiada także transport eoliczny.

Parametr spłaszczenia rozkładu uziarnienia $\left(K_{G}\right)$, niezależnie od czasu prowadzenia badań, przyjmuje zbliżone wartości w poszczególnych profilach. Odcinek, zlokalizowany w sąsiedztwie profilu I charakteryzują, w większości przypadków, osady o leptokurtycznym rozkładzie uziarnienia. Utwory o wysokim wskaźniku spłaszczenia nie są stabilne w sensie litodynamicznym (Racinowski i in. 2001). Osady korytowe na tym odcinku są rozmywane, transportowane i deponowane selektywnie, okresowo może występować także deficyt materiału osadowego (Szmańda 2010). Niskie wartości parametru kurtozy (rozkład platykurytczny), które lokalnie charakteryzują osady korytowe między profilami II a III oraz przy samym ujściu, świadczą o większej ilości osadu w środowisku sedymentacyjnym (Racinowski i in. 2001). Zauważyć należy, że w tych odcinkach zaznaczają się najwyraźniej zmiany położenia koryta. Transportowane osady, zwłaszcza przy brzegu wypukłym, podlegają depozycji. W profilach II, III i IV najliczniej występują osady o cechach rozkładów normalnych (mezokurytycznych), które charakterystyczne są dla warunków nasycenia materiałem mineralnym środowiska sedymentacyjnego. $\mathrm{Z}$ przedstawionej analizy wynika, że wskaźnik kurtozy podlega znacznym wahaniom, co świadczy o zmienności siły transportującej osad. Wniosek ten znajduje potwierdzenie w analizie wykresów zależności wskaźników uziarnienia $M_{Z}$ i $K_{G}$ (ryc. 6d). Wraz ze spadkiem średniej średnicy ziarn (wyrażonej w skali phi) następuje spłaszczenie rozkładów uziarnienia, co wskazuje na zmianę warunków z erozyjnych na akumulacyjne wraz z biegiem rzeki.

Analiza uziarnienia wykazała, że na tle innych cieków zlewni przymorza, na których prowadzono badania osadów korytowych w ujściowych odcinkach, osady Piaśnicy charakteryzują się najmniejszym zróżnicowaniem średniej średnicy ziarn oraz lepszym ich wysortowaniem (m.in. Dynus-Angiel 1983; Florek, Florek 1989; Szymczak 2014). Zakres zmienności parametru skośności i kurtozy nie odbiega znacząco od wartości uzyskanych w badaniach osadów rzek zlewiska Zalewu Puckiego (Redy, Kanału Łyskiego, Gizdepki, Potoku Błądzikowskiego i Płutnicy) (Szymczak 2014).

Wartości średnich prędkości przepływu zestawione z średnicą ziarn osadów korytowych, w diagramie Hjulströma lokalizowane są powyżej krzywej depozycji i świadczą o tym, że osady te są uruchamiane i transportowane. Zmierzone średnie prędkości przepływu $1 \mathrm{~m}$ nad dnem w profilu I zmieniały się w zakresie od $0,26 \mathrm{~m} \cdot \mathrm{s}^{-1}$ (I 2015) poprzez $0,27 \mathrm{~m} \cdot \mathrm{s}^{-1}$ (VI 2015) do 0,31 $\mathrm{m} \cdot \mathrm{s}^{-1}$ (XI 2014; XI 2015). Niewielkie zróżnicowanie prędkości przepływu jest charakterystyczne dla cieków o stałym, podziemnym zasilaniu. Zmiany parametru prędkości przepływu wyraźnie korelują 
z poziomem morza - im wyższy poziom, tym prędkość przepływu w ujściowym odcinku jest mniejsza.

Rozpatrując określone powyżej typy litologiczne osadów korytowych, w kontekście przedstawionych wartości prędkości przepływu, na podstawie diagramu Hjulströma (ryc. 7), można wnioskować, że w tych warunkach z osadów korytowych podrywane będą frakcje najdrobniejsze w przedziale 5-4 phi, których udział w osadach powierzchniowych jest niewielki (do 0,5\%). Transport tych osadów odbywa się w formie zawieszonej, podobnie jak piasków frakcji 4-1 phi, przy czym piaski średnioziarniste (2-1 phi) będą podlegały transportowi w saltacji i trakcji.

Wskaźniki $C$ i $M$ badanych próbek osadów korytowych na diagramie Passegi (1964; Passega, Byramjee 1969), wyraźnie grupują się w polach IV (80,95\%) oraz V (14,29\%). Obydwa pola wskazują na dominującą depozycję z zawiesiny przy niewielkim udziale ziarn drobniejszych od 0 phi akumulowanych z trakcji. Pole IV charakterystyczne jest dla rumowiska transportowanego w formie zawiesiny gradacyjnej oraz toczonego z udziałem saltacji w warunkach silnych ruchów turbulentnych. Pole V, w którym znalazły się wyłącznie próbki z profilu I, reprezentują ziarna transportowane w analogiczny sposób w warunkach umiarkowanej turbulencji (Szmańda 2010). Wśród osadów korytowych z profilu I (XI 2014; XI 2015) dwie próbki sklasyfikowane zostały w obszarze pola I, charakterystycznego dla materiału powstającego przy dużych prędkościach oraz znacznej turbulencji prądów przydennych, dlatego ziarna osadu są wleczone lub też toczone po dnie, a następnie deponowane z trakcji z niewielkim udziałem zawiesiny (Szmańda 2010).

\section{Wnioski}

Prowadzone badania potwierdziły wyraźny związek położenia koryta Piaśnicy ze zmieniającym się poziomem morza. Ujście rzeki, a tym samym jej koryto, w okresie prowadzenia badań przemieszczało się na odcinku 300 m wzdłuż linii brzegowej morza. Przy utrzymujących się wysokich poziomach morza (powyżej $540 \mathrm{~cm}$ ), na skutek podniesienia poziomu bazy erozyjnej, nastąpiło przesunięcie ujściowego docinka w kierunku wschodnim. Procesowi temu towarzyszy spadek prędkości przepływu w cieku. Im poziom morza był bardziej zbliżony do stanów średnich i niskich, tym bieg rzeki miał charakter wyraźnie prostoliniowy, a prędkości przepływu w rzece były większe. Wpływ na położenie i kształt ujścia miały także dominujące kierunki wzdłużbrzegowych prądów powierzchniowych, które „wyginają" ujście zgodnie ze swoim kierunkiem przemieszczania. W rezultacie ujście zakrzywiało się w stosunku do prostopadłego ułożenia koryta rzeki odpowiednio przy prądach z kierunku SE w lewą (zachodnią) stronę, przy prądach z sektora W w stronę prawą (wschodnią). 
Wyniki badań terenowych i laboratoryjnych wskazują, że litodynamika osadów korytowych nie jest warunkowana bezpośrednio zmianami poziomu morza. Decydujący wpływ na charakter osadów, na wszystkich opisanych odcinkach, mają procesy fluwialne oraz eoliczne. W obrębie wydzielonych profili (I-IV), zlokalizowanych w różnych częściach koryta, zauważono wyraźne różnice w wartościach wskaźników uziarnienia. Utrzymują się one na danych odcinkach niezależnie od istniejącego poziomu morza, choć pogłębiają się w skrajnie zarysowanej sytuacji wysokiego poziomu morza.

W badanym odcinku koryta występują piaski drobnoziarniste, które zastępowane są, wraz z biegiem rzeki, przez piaski średnioziarniste w znacznej części przenoszone do koryta rzecznego przez wiatr z wału wydmowego i plaży. Osady korytowe charakteryzują się umiarkowanie dobrym i dobrym wysortowaniem. Wartości prędkości przepływu, zmierzone w profilu I, potwierdzają wpływ tego parametru jako czynnika różnicującego osady korytowe. W środowisku zróżnicowanego przepływu wód na poszczególnych odcinkach większość osadów była transportowana w zawiesinie i saltacji z mniejszym udziałem trakcji. Zróżnicowanie parametru skośności i kurtozy wskazuje na zmianę warunków z erozyjnych na akumulacyjne wraz z biegiem rzeki.

\section{Literatura}

Allen G.P., Castaing P., Klingebiel A., 1972, Distinction of elementary sand populations in the Gironde Estuary (France) by r-mode factor analysis of grain-size data, Sedimentology, 19, 21-35.

Bajkiewicz-Grabowska E., Magnuszewski A., Mikulski Z., 1993, Hydrometria, Wydawnictwo Naukowe PWN, Warszawa.

Blott S.J, Pye K., 2001, Gradistat: A grain size distribution and statistics package for the analysis of unconsolidated sediments, Earth Surface Processes and Landforms 26, 1237-1248.

Bodziony M., 2011, Ujście Piaśnicy - cztowiek kontra przyroda, Ekonatura, 3, $26-27$.

Chow V.T., 1959, Open-channel hydraulics, McGraw-Hill, New York.

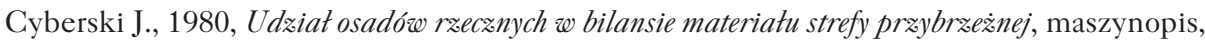
Instytut Morski, 43.

Dubrawski R., Zawadzka E. (red.), 2006, Przysztość ochrony polskich brzegów morskich, Zakład Wydawnictw Naukowych Instytutu Morskiego w Gdańsku, Gdańsk.

Dynus-Angiel J., 1983, Typy usiarnienia rumowiska dennego ræek pótnocnego sktonu Pomorza Zachodniego, Przegląd Geofizyczny, 28 (2), 185-193.

Florek E., Florek W., 1989, Cechy hydrologiczne Stupi a osady budujqce koryto, Kwartalnik AGH, Geologia 15 (1-2), 15-33.

Folk R.L., Ward W.C., 1957, Brazos River bar, a study of significance of grain size parameters, Journal of Sedimentary Petrology, 27, 3-26. 
Hjulström F., 1935, Studies of morphologica activity of rivers as illustrated by the River Fyris, Bulletin of the Geological Institute University of Uppsala, 25, 221-527.

Instytut Meteorologii i Gospodarki Wodnej (IMGW-PIB), 2014, Ocena wptywu obecnych i przysztych zmian klimatu na strefepolskiego wybræėa i i ekosystem Morza Battyckiego, Oddział Morski w Gdyni.

Instytut Morski w Gdańsku, 2012, Uwagi i komentarze ztożone w ramach konsultacji spotecznych projektu pn. „Prognoza oddziatywania na środowisko dla smiany programu wieloletniego na lata 2004-2023”, Program ochrony brzegów morskich, ustanowionego ustawa z dnia 28 marca 2003 r. o ustanowieniu programu wieloletniego „Program ochrony bræegów morskich”, wraz z odpowiedziami udzielonymi præez Autorów Prognozy, Instytut Morski, Gdańsk.

Jarzębińska T., Majewski W., 2009, Influence of Pumped-Storage Power Plant on Physical and Ecological State of Lake Żarnowiec, [w:] International Symposium of Water Management and Hydraulic Engineering, paper A101, Ohrid, 349-360.

Kondracki J., 2002, Geografia regionalna Polski, Wydawnictwo Naukowe PWN, Warszawa.

Leontjew O.K., Nikiforow L.G., Safjanow G.A, 1982, Geomorfologia bræegów morskich, Wydawnictwa Geologiczne, Warszawa.

Łabuz T.A., Sydor P., 2016, Litologia osadow powieræchniowych wydm præednich jako wskaænik procesów eolicænych na akumulacyjnych odcinkach polskiego wybræėa, [w:] J. Święchowicz, A. Michno (red), Wybrane sagadnienia geomorfologii eolicznej. Monografia dedykowana dr hab. Bogdanie Izmaitow w 44. rocznice pracy naukowej, Instytut Geografii i Gospodarki Przestrzennej UJ, Kraków, 63-86.

Majewski W. (red.), 1996, Stan jeziora Żarnowieckiego po 10 latach eksploatacji elektrowni szczytowo-pompowej, Oficyna Wydawnicza Politechniki Warszawskiej, Warszawa.

Musielak S., 2015, Wptyw zmian klimatycznych i cyrkulacji wód na morfodynamikę bræegów Potudniowego Bałtyku, Streszczenia wykładów konferencyjnych, Konferencja „Bałtyk 2015”, Sopot 14-16 września 2015, 1-5, http://www.iopan.pl/baltyk2015/materialy/StreszczeniaWykladowKonferencyjnych/17_WplywZmianKlimatycznych.pdf.

Mycielska-Dowgiałło E., 2007, Metody badań cech teksturalnych osadów klastycznych $i$ wartośc interpretacyjna wyników, [w:] E. Mycielska-Dowgiałło, J. Rutkowski (red.), Badania cech teksturalnych osadow czwartorzędowych i wybrane metody oznaczania ich wieku, Wydawnictwo Szkoły Wyższej Przymierza Rodzin, Warszawa, 95-180.

Mycielska-Dowgiałło E., Ludwikowska-Kędzia M., 2011, Alternative interpretations of grain-size data from Quaternary deposits, Geologos 17 (4), 189-203.

Myślińska E., 2010, Laboratoryjne badania gruntów i gleb, Wydawnictwa Uniwersytetu Warszawskiego, Warszawa.

Myśliwy M., 2010, Riparian tall herb fringe communities in a small lowland rivervalley: Species-environment interactions, Natura Montenegrina, 9 (3), 403-415.

Ostaficzuk S., Jakubicz B., Skompski S., 1976, Szczegótowa mapa geologiczna Polski w skali 1: 50 000. Arkusz Stawoszyno, Wydawnictwa Geologiczne, Warszawa.

Ostaficzuk S., 1978, Objaśnienia do szczegótowej mapy geologicznej Polski. Arkusz Stawoszyno, Wydawnictwa Geologiczne, Warszawa. 
Passega R., 1964, Grain-size representation by CM patterns as a geological tool, Journal of Sedimentary Petrology, 34, 830-847.

Passega R., Byramjee R., 1969, Grain size image of clastic deposits, Sedimentology, 13, 830-847.

Podziat hydrograficzny Polski, 1983, Cz. I: Zestawienia liczbowo-opisowe, Instytut Meteorologii i Gospodarki Wodnej, Warszawa, 847-848.

Przasnyska J., 2009, Mapa litogenetyczna Polski 1: 50 000. Arkusz Stawoszyno, Ministerstwo Środowiska.

Racinowski R., Szczypek T., Wach J., 2001, Prezentacja i interpretacja wyników badań uziarnienia osadow czwartorzędowych, Wydawnictwo Uniwersytetu Śląskiego, Katowice.

Radtke G., Bernaś R., Dębowski P., Skóra M., 2010, Ichtiofauna matych cieków polskiego wybrzeża Battyku, Roczniki Naukowe Polskiego Związku Wędkarskiego, 23, 79-96.

Szmańda J.B., 2010, Litodynamiczna interpretacja środowiska fluwialnego na podstawie wskaźników usiarnienia - przeglad wybranych metod, Landform Analysis, 12, 109-125.

Sztobryn M., Letkiewicz B., Mykita M., Kowalska B., Cieślak A., 2010, Metodyka obliczania maksymalnych poziomów wody o określonym prawdopodobieństwie przewy:szenia dla wybræe:̇a oraz ujsciowych odcinków ræek będqcych pod wptywem oddziatywania mor:a w celu wykorzystania wyników do modelowania hydrodynamicznego, a następnie opracowania map sagrożenia powodziowego oraz map ryzyka powodziowego. Raport z wykonania map zagrożenia powodziowego i map ryzyka powodziowego, Instytut Meteorologii i Gospodarki Wodnej, Oddział Morski w Gdyni.

Szymczak E., 2002, The transport of material by the rivers of the northern slope of the Pomeranian Lakeland to the Baltic Sea, Oceanological Studies, 31 (3-4), 85-97.

Szymczak E., 2014, Osady korytowe cieków zlewiska Zalewu Puckiego w świetle analiz teksturalnych, [w:] R. Cieśliński, K. Jereczek-Korzeniewska (red.), Problemy badań wody w XX i XXI wieku, Wydawnictwo Uniwersytetu Gdańskiego, Gdańsk, 374-386.

Szymczak E., Piekarek-Jankowska H., 2007, The transport and distribution of the river load in the Puck Lagoon by the mouth of the river Reda (Southern Baltic Sea, Poland), Oceanological and Hydrobiological Studies, 36 (1), 103-124.

Szymczak E., Szmytkiewicz A., 2014, Sediment deposition in the Puck Lagoon (Southern Baltic Sea, Poland), Baltica, 27 (2), 105-118.

Walling D.E., Fang D., 2003, Recent trends in the suspended sediment loads of the world's rivers, Global and Planetary Change, 39, 111-126.

Wolski T., Wiśniewski B., 2014, Long-term, seasonal and short-term fluctuations in the water level of the Southern Baltic Sea, Quaestiones Geographicae 33 (3), 181-197.

Visher G.S., 1969, Grain-size distributions and depositional processes, Journal of Sedimentary Petrology, 39,1074-1106.

Zawadzka-Kahlau E., 2008, Morfologiczne efekty oddziatywania czynników hydrometeorologicznych na Mieræei Karwieńskiej, Landform Analysis, 88-93. 


\title{
Źródła internetowe
}

Komunalny Związek Gmin Dolina Redy i Chylonki, http://kzg.pl/index.php/srodowisko_geograficzne,wody_powierzchniowe,rzeki_potoki_kanaly (12.04.2016).

Geoportal 2, http://mapy.geoportal.gov.pl/imap/ (16.07.2017).

Model Ekohydrodynamiczny Instytut Oceanografii, Uniwersytet Gdański, http://model. ocean.univ.gda.pl/ (10.12.2016).

Ujście Piaśnicy do morza, https://www.youtube.com/watch?v=rUY51NRaiQU (8.02.2017).

\author{
Ewa Szymczak \\ Uniwersytet Gdański \\ Wydziat Oceanografii i Geografii \\ al. Pitsudskiego 46, 81-578 Gdynia \\ ewa.szymczak@ug.edu.pl \\ Dorota Zabłocka \\ Uniwersytet Gdański \\ Wydziat Oceanografii i Geografii \\ al. Pitsudskiego 46, 81-578 Gdynia \\ dorota.pietruszka1@gmail.com
}

